\title{
Economics of climate change and green employment: A general equilibrium investigation for Turkey ${ }^{\text {it }}$
}

\author{
Gunes Kolsuz $^{\mathrm{a}, *}$, A. Erinc Yeldan ${ }^{\mathrm{b}}$ \\ a Bilkent University, Department of Political Science and Public Administration, Turkey \\ b Bilkent University, Department of Economics, Turkey
}

\section{A R T I C L E I N F O}

\section{JEL classification:}

C68

$\mathrm{O} 44$

Q56

Q58

Keywords:

Climate change

Green jobs

Computable general equilibrium

Turkey

\begin{abstract}
A B S T R A C T
This paper quests for the intrinsic complementarities among environmental pollution abatement, induced technological innovation to combat human-induced climate change, targeted expansions for green employment, and enhanced welfare through gains in private income. Utilizing data from the Turkish economy, we implement an applied general equilibrium model to study the synergies between environmental abatement instruments and policies towards sustaining green jobs. Our results are indicative that by a proper mix of environmental taxation and technological and institutional innovations, Turkey can serve as an example for a host of developing countries in setting the stage for a pro-employment and eco-friendly, sustained growth path. We further show that for the successful implementation of a carbon emissions mitigation strategy, elimination of the burden of existing labor taxes and factor market distortions are crucial. Our analysis suggests that complemented with a strategy of substitution of environmental taxes against the existing distortionary labor taxes, costs abatement on domestic income and employment could be negligible.
\end{abstract}

\section{Introduction}

Accumulated evidence on the extend and nature of human-induced climate change calls for more intensive research on environmentalfriendly, sustained growth and patterns of induced technological innovations together with enhanced job opportunities and social welfare. According to the Intergovernmental Panel on Climate Change (IPCC), for our planet to have a $50 \%$ chance of avoiding an undesirable rise in the global average temperature by $2^{\circ}$ (Celsius), concentrations of greenhouse gases ought to be stabilized at $450 \mathrm{ppm}$ (parts per million) of carbon dioxide equivalent $\left(\mathrm{CO}_{2} e\right)$. This means a total carbon budget of 870-1240 gigatons of $\mathrm{CO}_{2} e$ for the future viability of our planet.

Yet, many argue that the global target of $450 \mathrm{ppm}$ is already too high. The Wild World Foundation (WWF) argue, for instance, that we should not allow for a rise in average global temperature by more than $1.5^{\circ} \mathrm{C}$. Instead, the WWF calls for a concentration limit of $400 \mathrm{ppm}$ $\mathrm{CO}_{2} e$ to have a better chance of maintaining the rise in global temperatures at less than $2{ }^{\circ} \mathrm{C}$. Having $\mathrm{GHG}$ concentrations that already reached to $496.2 \mathrm{ppm}$ by 2012 , and given the fact that the rise in the average global temperature has already surpassed $0.8^{\circ} \mathrm{C}$ over the last century, the WWF calls for immediate action that goes beyond the standard instruments of taxes and subsidies for mitigation.

Instruments of environmental policy thus far consisted mainly of carbon tax-cum-subsidies, as well as administering energy markets often through high taxes both on the user and also the supplier side. However, it is now a well-documented observation that price instruments, administered through the market optimization alone, will not suffice to achieve the broad objectives of controlling global GHG concentrations, nor maintaining a sustainable and eco-friendly growth path. Part of the problem is due to the fact that development of new eco-friendly technologies typically involve positive spillovers in the form of agglomeration effects, knowledge diffusion, cross-firm externalities and industry-wide learning; and yet, the decentralized optimization embedded in the laissez-faire actions of the markets may fail to capture these positive spillovers, and competitive equilibrium may fail

\footnotetext{
Findings of this research rely in part on the background paper to Turkey's contribution the United Nations Conference on Sustainable Development, Rio +20, Rio de Janeiro, 2012.

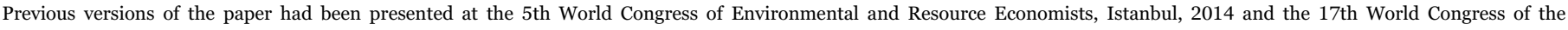

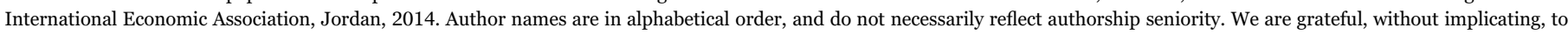

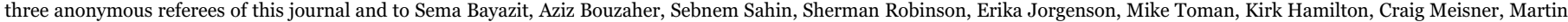
Riser, Sevil Acar and Erol Cakmak, for their comments and suggestions.

* Corresponding author.

E-mail addresses: gunes.kolsuz@bilkent.edu.tr (G. Kolsuz), yeldane@bilkent.edu.tr (A.E. Yeldan).
} 
achieving the social optimum. ${ }^{1}$

More importantly, decentralized laissez faire market equilibrium based on private optimization faces the danger of path dependence; that is, firms may be caught up specializing in dirty technologies. Path dependence of innovation may lead firms to innovate towards maintaining dirty technologies Aghion [4,7]. Firms with a history of dirty innovations tend to follow that path, creating path-dependence in the long run. Thus, Aghion warns that with a narrow set of instruments, limited only to carbon taxes and energy prices, it will take a very long time for the clean innovations to catch up with the dirty technologies; and calls for complementing the carbon tax with broader set of macroeconomic policy instruments that involve interventions towards "green technologies", as well as "green employment" [7].

Lozschel noted that for global climate change modeling the traditional approach of regarding technical progress a purely exogenous variable is misplaced [8]. In contrast, firms will tend to generate endogenous responses to policy shocks through adopting corporate investment in $\mathrm{R} \& \mathrm{D}$ to innovate in technologies to minimize the tax burden. Such responses may take the form of knowledge spillovers (Goulder and Mathai [9]); optimization on investment and R \& D effort (Nordhaus [10]; Buonanno, et al., [11]); and spillover effects through conglomerations (Griliches [12]; Goulder and Schneider [13]).

In nutshell, while it is generally understood that tighter environmental standards will be costly, Porter and van der Linde [14] confirm, with a series of case studies, that properly designed regulation via a broad spectrum of market-based instruments such as taxes and/or capand-trade emissions allowances can in fact stimulate innovations. This notion, later to be known as the Porter hypothesis, suggests that the evidence is more supportive of the "weak" version (i.e., stricter regulation leads to more innovation), rather than the "strong" version of the hypothesis (i.e., business performance follows stricter regulation with a win-win outcome) $[15,16]$.

This paper is a follower of this broad literature with an application to the Turkish micro and macro economic data. It extends this strand by incorporating the nature of labor markets and opportunities of green employment into the policy analysis. Thus, what is pursued is a simultaneous achievement of sustainable patterns of growth together with environmental pollution abatement, increased employment opportunities, and a higher rate of private income. This triple-dividend of "win-win-win" strategy framework rests on rationalization of the public taxation structure by way of replacing the distortionary tax burden on labor, and utilization of the tax funds to stimulate innovations towards greener technologies.

Various applications of the triple dividend had been noted in the literature. $^{2}$ It is the purpose of this paper to present a real-world application of this conceptualization to the Turkish economy. In terms of greening, Turkey's economy is characterized by low, albeit rapidly increasing environmental footprint. Contrasted against the OECD economies and the world at large, Turkey displays a medium role in terms of gaseous emissions (see Table 1). As of 2012, Turkey's per capita $\mathrm{CO}_{2}$ emissions stand at 4.04 tons, it scores significantly below the OECD average of 9.68 tons. In comparison the global average of 4.51 tons per capita, Turkey is seen almost around the median.

Yet, if Turkey's missions are contrasted on the basis of carbon efficiency, that is, $\mathrm{CO}_{2}$ emissions per \$ GDP, Turkey's scores are observed to be less successful. In 2012 Turkey's $\mathrm{CO}_{2}$ emissions per $\$$

\footnotetext{
${ }^{1}$ For various analytical perspectives to this end, see, e.g., Rodrik (Chapter 4), Aghion et al. [1-4], The original idea rests on Romer and Krugman $[5,6]$.

2 See, e.g., Kurabayeva, [17]; Bowen, [18], Goulder, [19], and Bovenberg and de Mooij, [20]. Telli, Voyvoda and Yeldan, [21] study rationalization of the tax burden for the Turkish economy in the context of the macroeconomics of the Kyoto Protocole, while Akin and Yeldan [22] focus on macroeconomics of possible integration of the Turkish polluters in to the European carbon market. Adaman et al. [23] explored Turkish urban households' willingness to pay (WTP) for $\mathrm{CO}_{2}$ emission reductions expected to result from improvements in power production.
}

GDP was $0.49 \mathrm{~kg}$. This was 0.31 among the OECD countries; while the world average was 0.58. If a comparison is made over to the 1990 levels, we observe that carbon efficiency improved significantly across the world and the OECD members, while for Turkey one observes a rise from 0.47 in 1990 to 0.49 in 2012 (kg/\$GDP). As such, these trends reveal that Turkey has not yet decoupled its economic growth from rising energy use, a process that has been underway in advanced economies for more than two decades. In fact, Aşıci, provides strong evidence that "the economic growth path taken in the 2003-2009 period has gradually become both more energy and pollution intensive as compared to the 1995-2002 period" (Aşıc1. [24]) Some of the reasons beyond this increase of pollution intensity are due to domestic fiscal policy. A recent CGE modeling work by Acar and Yeldan studied the effect of fiscal subsidies on coal on aggregate $\mathrm{CO} 2$ emissions and found that elimination of these subsidies could have reduced gaseous emissions by $5.5 \%$ over the base run trajectory through $2015-$ 2030 [25].

Data reveal that Turkey's total $\mathrm{CO}_{2}$ (eq. ) emissions are at 467.6 million tons as of 2014. Projections by the Sweedish EcoEquity Institute suggest that total $\mathrm{CO}_{2}$ emissions will reach to 680 million tons by 2030 under a scenario of "low committment". In Fig. 1 we display aggregate emissions and its sectoral distribution over 1990-2014. The rapid expansion of the energy combustion in total gasesous emissions can be easily identified from Fig. 1. Of the total $467.6 \mathrm{~m}$ tons of $\mathrm{CO}_{2}$ emissions in $2014,339 \mathrm{~m}$ tons are estimated to be derived from fossil fuel combustion for energy production. Industrial processes also expand their share over this period with an added $62.8 \mathrm{~m}$ tons of gaseous emissions.

As indicated above, taxation of energy inputs had been the main policy norm across the OECD. Environmental taxes average around $2.5 \%$ as a ratio to the aggregate GDP across the OECD countries, yet with significant divergences ranging from $0.5 \%$ in Mexico, and $0.9 \%$ in USA to $3.7 \%$ in Turkey, $3.8 \%$ in Netherlands, and $4.7 \%$ in Denmark. Fig. 2 gives a snapshot of the relationship between the burden of the environmental taxes and the average gains in $\mathrm{CO}_{2}$ abatement for the OECD countries over the last two decades.

The extensive set of observations with continued positive trends in carbon emissions, in spite of the tax burden, is suggestive of the fact that without the accompanying technological innovations the gains in emission abatements will be rather small. Fig. 2 is affirmative of the caution laid by Aghion above (2014) arguing that there is significant path dependence across the polluters globally. Consequently, without additional resort to targeted innovations that could break the chain of path dependence, reliance on taxation and market prices alone does not suffice in succeeding viable reductions in emissions [7]. Fig. 3 follows this line with a direct focus for Turkey. The burden of environmental taxes stand at a significant rate reaching to as much as $4 \%$ to the GDP across the last decade. Yet, this burden does not seem to have much of an effect on $\mathrm{CO}_{2}$ abatement, with a secular rise in aggregate emissions at a rate of almost 5\% per annum over 1990-2014.

All these reveal the difficulties in associating instruments of abatement to achieve a more stable and controlled environment for energy demand. In such an unstable and abrupt path of energy demand, it is virtually quite hard to project the future path of emissions whether from fuel combustion to generate energy, or from industrial processes. Against this uncertain structure, it is not hard to argue that the current arsenal of Turkish environmental policies that rely mostly on energy taxes will not suffice to achieve significant results for mitigation. Taxing carbon emissions directly to enhance $\mathrm{CO} 2$ abatement is traditionally regarded as the most efficient instrument. This verdict had been formulated as early as 1920 by Pigou [26]. However, in the developing world (and even in many today's developed economies) relying solely on the disciplinary penalties of direct carbon taxes to mitigate $\mathrm{CO} 2$ emissions will likely not suffice. This is because these economies typically lack the institutional infrastructure to effectively monitor the source of emissions as well as to administer broadly a 
Table 1

Carbon Emissions and Energy Intensities Source: US Energy Information Association.

\begin{tabular}{|c|c|c|c|c|c|c|c|c|c|}
\hline & \multicolumn{3}{|l|}{1990} & \multicolumn{3}{|l|}{2000} & \multicolumn{3}{|l|}{2012} \\
\hline & World & OECD & Turkey & World & OECD & Turkey & World & OECD & Turkey \\
\hline Total $\mathrm{CO}_{2}$ (Million Ton) ${ }^{1}$ & 20,974 & 11,140 & 126.9 & 23,756 & 12,615 & 200.6 & 31,734 & 12,146 & 302.4 \\
\hline Total $\mathrm{CO}_{2}$ per capita ${ }^{2}$ & 3.977 & 10.413 & 2.303 & 3.898 & 10.929 & 3.122 & 4.510 & 9.684 & 4.037 \\
\hline $\mathrm{CO}_{2} / \$ \mathrm{GDP}^{3}$ & 0.687 & 0.444 & 0.471 & 0.591 & 0.385 & 0.519 & 0.581 & 0.308 & 0.482 \\
\hline Energy Consumption/\$ GDP ${ }^{4}$ & 11,350 & 7904 & 7326 & 10,047 & 7243 & 8193 & 9991 & 6228 & 8129 \\
\hline
\end{tabular}

${ }^{1}$ Total $\mathrm{CO}_{2}$ Emissions from combustion of energy (Million metric tons).

${ }^{2}$ Metric tons of $\mathrm{CO}_{2}$ per person.

${ }^{3}$ Metric tons of $\mathrm{CO}_{2}$ per 1000 per year 2005 \&, using market exchange rates.

${ }^{4}$ Metric tons of $\mathrm{CO}_{2}$ per 1000 per year $2005 \$$, using market exchange rates

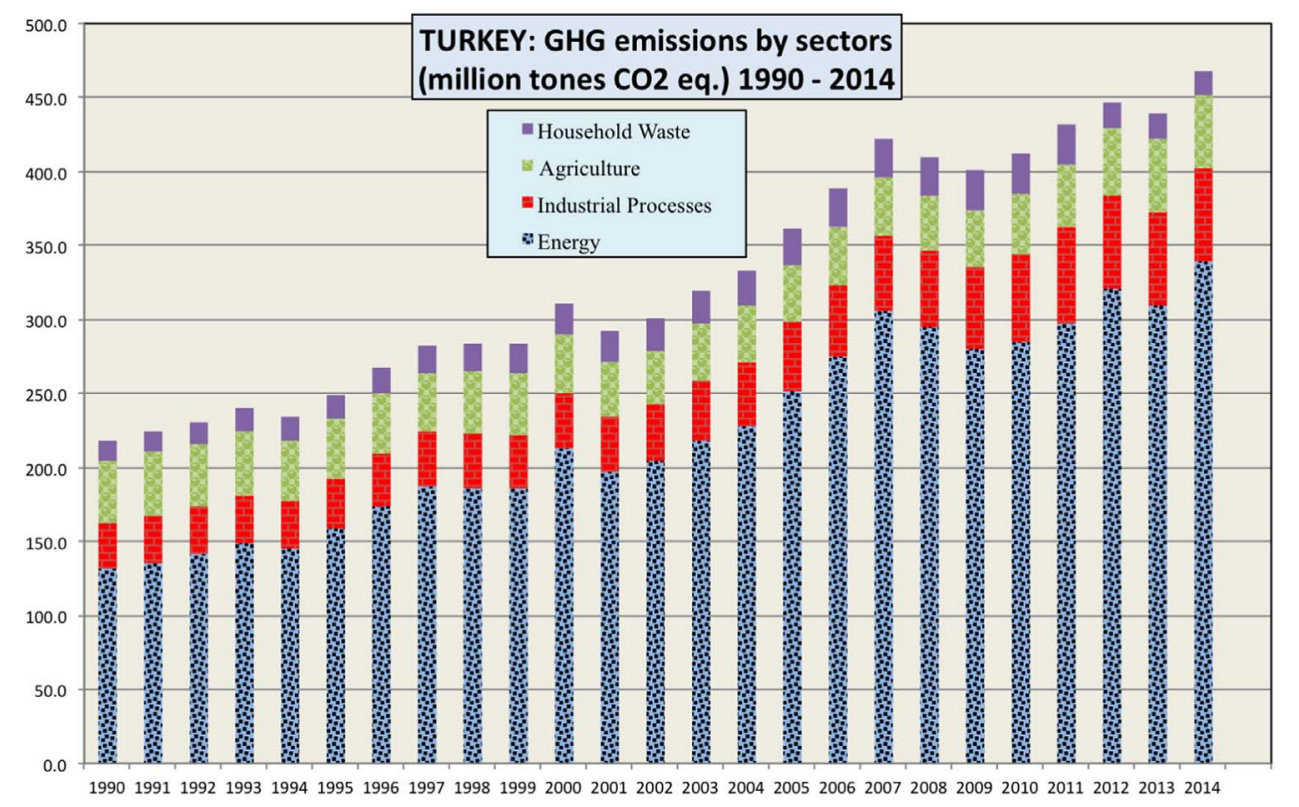

Fig. 1. Turkey GHG Emissions by Sectors.

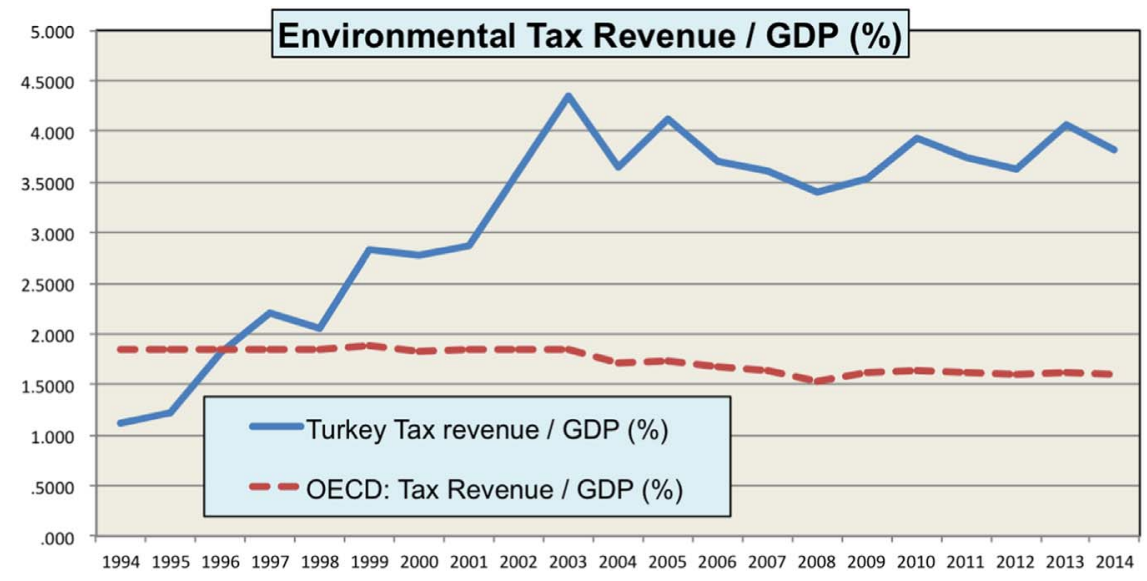

Fig. 2. Environmental Tax Revenue/GDP.

market structure of tradable permits in carbon exchange. Furthermore, given the threat of path-dependence indicated above, without resorting to technological change and maintaining the existing distortions in the factor markets, reliance solely on carbon taxation will not be effective in pursuing abatement objectives.

Fullerton and Metcalf [27] for instance caution that textbook implementation of carbon taxes solo, without taking notice pf the existing distortionary framework in the commodity and factor markets may "miss the target". Devarajan et al. [28] also argue in the context of the South African economy, that the interaction between energy taxation and the modes of adaptation of the pollution intensive sectors "rely critically on other distortions in the system and on structural rigidities in the economy". Using a CGE modeling approach, they pursue the implications of using the existing tax instruments on energy mix to " mitigate CO2 emissions in a second best environment characterized by labor market distortions" (Devarajan et al. [11]: 1). Their findings suggest that removal of the existing institutional distortions in the labor markets will likely to have a profound impact 
Turkey: Environmental Taxes and CO2 Emissions

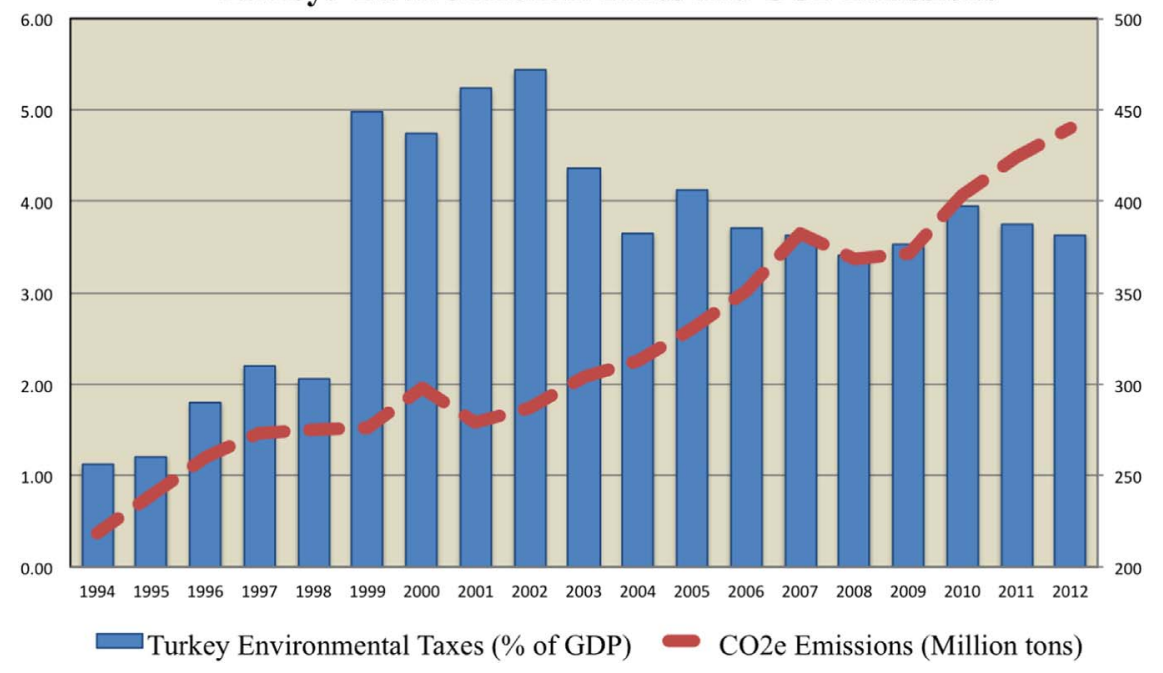

Fig. 3. Turkey Environmental Taxes and $\mathrm{CO}_{2}$ Emissions.

on the welfare outcomes of possible carbon taxation.

We extend these ideas in various ways: first, we document with the aid of our applied general equilibrium modeling apparatus that in the absence of corrective action, Turkey's $\mathrm{CO}_{2}$ emissions both in per capita and per \$GDP values will increase substantially under the unfettered dynamics of business-as-usual. Then we intervene and simulate the implementation carbon taxation along the polluter-pays-principle. As an extension of ultimate policy formulations we utilize the tax revenues to earmark a wage fund for creating an environmental abatement sector -the so called "green jobs". Thirdly, we study the effects of innovations on the new technologies of carbon mitigation to break away with the Aghionesque path-dependence discussed above in the introduction. We further introduce an endogenous technological innovation mechanism driven by expected improvements in health, and study the implied gains for the Turkish case. Finally, the analysis extends over the reduction of rigdities and tax distortions in the labor markets.

Our results are indicative that by a proper mix of environmental taxation and technological and institutional innovations along those extensions, Turkey can serve as an example for a host of developing countries in setting the stage for a pro-employment and eco-friendly, sustained growth path. We further show that for the successful implementation of a carbon emissions mitigation strategy, elimination of the burden of existing labor taxes and factor market distortions are crucial. Our analysis suggests that complemented with a strategy of substitution of environmental taxes against the existing distortionary labor taxes, costs abatement on domestic income and employment could be negligible.

Thus, the main hypothesis in this paper is that taxation policies need to be complemented with policies towards directly increasing the carbon efficiency and generating green jobs. All these call for an overall assessment of the macroeconomic structure within the discipline of general equilibrium, as in the absence of such an integrated framework the effectiveness of such policy interventions and their economic impacts are quite hard to quantify.

Formally, to address these questions, we make use of an applied macroeconomic structure for the Turkish economy to investigate the possible effects of various abatement policy instruments designed to lead technology adoption and to achieve higher employment and sustainable growth patterns. The model is within the Computable General Equilibrium (CGE) tradition. It dynamically portrays the 2015-2030 growth trajectory of the Turkish economy with a detailed emphasis on gaseous pollutants, sectorial production and employment patterns and savings - investment balance.
The paper is organized as follows: Next, in section II we introduce the salient features of the algebraic equations of the CGE model along with the data sources. In section III we report on the results of our policy analysis, using the CGE apparatus as a social laboratory. Next, data sources for the model and the business-as-usual base path is discussed. Section four offers policy discussions, while section five concludes.

\section{Analytical model}

\subsection{The algebraic structure of the computable general equilibrium model $^{3}$}

The CGE model that had been utilized in this paper is an extension of a broad tradition of applied general equilibrium modeling framework for the Turkish economy as laid out by the seminal works of Telli et al. [29], Sahin [30], Kumbaroglu [31] and Bouzaher et al. [32]. Here, we extend the CGE apparatus to cover labor market issues and the concept of "green jobs", together with an endogenous innovation structure to capture the innovative gains associated with earmarking of the environmental taxes. Under this extension, the supply-side of the economy is modeled as twelve aggregated sectors. The "factors" of production are distinguished in the standart fashion with capital, labor, a composite of primary energy inputs, and other intermediate inputs serve as the primary inputs. Energy composite is aggregated over the intermediate inputs of electricity, petroleum and gas and coal sectors. Sectorial production is modeled via a multiple-stage production technology. At the "top" stage we specify output supplies by way of a standart, and yet augmented, Cobb-Douglas functional. In agriculture, we added land aggregate as an additional composite factor of production where land is further aggregated over irrigated and rain-fed land components within a constant elasticity of substitution (CES) formulation. Water used in irrigated land is found in fixed ratios to quantity of land.

Thereby, the sectorial production technology is given as:

$X S_{i}=A X_{i}\left[K_{i}^{\lambda_{L, i}} L_{i}^{\lambda_{L, i}}\left(\prod_{j} I D^{\lambda_{I D, j, i}}\right) E N G^{\lambda_{E, i}}\right]$

whereas in agriculture, we further augment the factors of production

\footnotetext{
${ }^{3}$ This section is borrowed from the technical description of the earlier versions of the CGE model as narrated in Bouzaher, Sahin and Yeldan [32]. Further documentation of the extended model is available from the authors upon request.
} 
with the composite land aggregate.

In Eq. (1), $A X$ is the technology index parameter, $K$ is the physical capital stock; $L$ is labor input; and $E N G$ is he aggregate energy composite input utilized in sector $i$. The parameters $\lambda_{K, i}, \lambda_{L, i}$, and $\lambda_{E, i}$ denote the shares of capital input, the labor input, and the composite energy input for sector $i$. Under the assumption of constant returns to scale (CRS) technology, for every sector $i$ we must have the following identity:

$\lambda_{K, i}+\lambda_{L, i}+\sum_{j} \lambda_{I D, j, i}+\lambda_{E, j}=1$

Under the second stage, we specify the composite energy input. This is composed of coal, petroleum and gas and electricity and is thought to be "produced" within a CES functional that submits substitution possibilities across its primary sources of energy:

$E N G_{i}=A E_{i}\left[\mathcal{K}_{C O, i} I D_{C O, i}^{-\rho x_{i}}+\mathcal{K}_{P G, i} I D_{P G, i}^{-\rho x_{i}}+\mathcal{K}_{E L, i} I D_{E L, i}^{-\rho x_{i}}\right]^{-1 / \rho x_{i}}$

Under the above "production" technology, the sectoral demand for coal, petroleum and gas and electricity are found from the optimum conditions of cost minimization:

$\frac{I D_{C O, j}}{E N G_{i}}=\left[\frac{[}{[}[] \mathcal{K}_{C O, i} P E G_{i} A E_{i}^{-\rho x_{i}}\left(1+C O_{2} \operatorname{tax}_{C O}+P M 10 \operatorname{tax} N_{C O}\right) P C_{C O}^{1 /\left(1+\rho x_{i}\right)}\right.$

$\frac{I D_{P G, j}}{E N G_{i}}=\left[\frac{[}{[}[] \mathcal{K}_{P G, i} P E G_{i} A E_{i}^{-\rho x_{i}}\left(1+C O_{2} \operatorname{tax}_{C O}+P M 10 \operatorname{tax}_{C O}\right) P C_{P G}^{1 /\left(1+\rho x_{i}\right)}\right.$

$\frac{I D_{E L, j}}{E N G_{i}}=\left[\frac{[}{[}[] \mathcal{K}_{E L, i} P E G_{i} A E_{i}^{-\rho x_{i}}\left(1+C O_{2} \operatorname{tax}_{C O}+P M 10 \operatorname{tax} N_{C O}\right) P C_{E L}^{1 /\left(1+\rho x_{i}\right)}\right.$

where we denote the "aggregate" cost of the energy composite by $P E G$, and $\mathrm{CO}_{2} \operatorname{taxN}_{j}$ and $P M_{10} \operatorname{taxN}_{j}$ stand for the relevant environmental tax rates.

Sectorial demands for labor and physical capital can be found thorough a standart application of the principle of cost minimization subject to the production function specified in Eq. (1).

The equations above govern the utilization of the primary energy inputs and provide the pertinent set up for the effects of alternative abatement instruments on gross supplies of sectorial output levels. A tax on the usage of coal for instance, would shift the demand away from coal as a primary source of energy towards other sources, under the allowances of substitutability determined by the production technology. Given the coefficients of gaseous pollution from unit coal combustion, we can trace out the level of $\mathrm{CO} 2(e q)$ emissions emanating from coal combustion in energy generation.

Labor markets are resolved through both flexible wage rates (rural labor market) and via quantitative adjustments on employment (in the urban labor market). This leads to a dualistic structure where rural and urban labor are differentiated. Within dynamic adjustment processes in the long run, rural labor migrates into urban labor market through the adoption of a simple Harris-Todaro specification. Here rural labor is thought to respond to the expected urban wage rate and rural wage differences and migrates through:

$L M I G=\mu \frac{\left(E W U-W_{A G}\right)}{W_{A G}} L S U P_{A G}$

$E W U=W_{U R B} \sum_{i \in N o n-A g}\left(\begin{array}{c}L_{i}^{D} \\ L S U P_{U R B}\end{array}\right)$

where $W_{A G}$ and $W_{U R B}$ denote the rural and urban wage rates, respectively; and $E W U$ is the expected urban wage rate. The parameter $\mu$ is a scaling (calibration) indicator. Likewise, given the aggregate physical capital stock supply in each period, the capital market equilibrium implies an equilibrium profit rate $r$ for the economy. Consequently, sectoral physical capital is mobile and responds to the difference in profit rates to allocate the total investment funds across "time".

\subsection{Modeling of gaseous pollutants}

In this model we exclusively focus on two types of environmental pollution: gaseous emissions (in terms of $\mathrm{CO}_{2}$ equivalents and PM10) and solid \& water waste. Waste is thought to be discharged by way of (1) urban waste from household consumption; (2) waste from industrial processes, and (3) waste from water usage in agricultural production.

As for the gaseous sources of $\mathrm{CO}_{2}$ and PM10 emissions, we accommodate the following specifications: emissions rise (i) due to industrial processes, (ii) due to (primary and secondary) energy generation, and (iii) due to energy demand of households. Total $\mathrm{CO}_{2}(e q)$ emissions are generated through various manners. The emissions from industrial processes depend on the level of industrial gross supplies, and are regarded proportional to gross output:

$C \mathrm{O}_{2} E M_{i}^{I N D}=\overline{\delta_{i}} X S_{i}$

Total emissions due to energy usage, $\mathrm{TOTCO}_{2} E N G$ are generated from two sources: sectoral emissions due to combustion of primary energy fuels (coal and petroleum and gas) and sectoral emissions due to combustion of secondary energy fuels (refined petroleum). Under both sources, the mechanism of emission is dependent on the level of pollutant-emitting inputs (energy input at primary and at secondary levels) in each sector:

$C O_{2} E M_{j, i}^{E N G}=\bar{\omega}_{j, i} I D_{j, i} \quad j=C O, P G$

$C O_{2} E M_{j, i}^{I N M}=\bar{\varepsilon}_{j, i} I D_{j, i} \quad j=R P$

with $\bar{\omega}_{j, i}$ and $\bar{\varepsilon}_{j, i}$ denoting pollution emissions on relevant energy sources as a ratşo of intermediate input usage. Total emissions of $\mathrm{CO}_{2}$ from the consumption demand of energy by households is given by:

$\mathrm{TOTCO}_{2} \mathrm{HH}=\sum_{i} \overline{\Psi_{i}} \mathrm{CD}_{i}$

Here, $\overline{\Psi_{i}}$ is the coefficient of emissions of $\mathrm{CO}_{2}$ in private consumption $\left(C D_{i}\right)$ of the basic fuels coal (CO) and refined petroleum (RP) by households.

\subsection{Income generation and general equilibrium}

Private household income is composed of labor's wage incomes, rental income on land and remittances of profits from the enterprise sector. In turn, the public sector revenues comprise tax revenues from wage and profit incomes, and non tax sources of income from various exogenous flows. The income flow of the public sector is further augmented by indirect taxes and environmental taxes. Table 2 below lists the arsenal of environmental taxes.

The model follows the fiscal budget constraints closely. Current fiscal policy stance of the government is explicitly recognized as specific targets of primary (non-interest) budget balance. We regard the government transfer items to the households, to the enterprises and to the social security system as fixed ratios to government revenues net of interest payments. Then, under a pre-determined primary surplus/ GDP ratio, public investment demand is settled as a residual variable out of the public fiscal accounts. The public sector borrowing requirement is either financed by domestic or foreign borrowing. The overall model is brought into equilibrium through endogenous adjustments of product prices to clear the commodity markets and balance of payments accounts. The real exchange rate serves as the numériare of the system. 
Table 2

Tax instruments used in the CGE model.

\begin{tabular}{ll}
\hline CO2TAXP & $\mathrm{CO}_{2}$ Tax on sectoral output \\
CO2TAXN(I) & $\mathrm{CO}_{2}$ Tax on intermediate input use \\
C02TAXC(I) & $\mathrm{CO}_{2}$ Tax on consumer demand \\
PM10TAXP & $P M 10$ Tax on sectoral output \\
PM10TAXN(I) & $P M 10$ Tax on intermediate input use \\
PM10TAXC(I) & $P M 10$ Tax on consumer demand \\
WASTETAX & Waste tax on households \\
WASTETAXIND & Waste tax on industry \\
WSUTAXHH & Waste water tax on households \\
TAXWSUIND & Industrial waste water tax \\
TAXNITAG & Tax on fertilizer use in agricultural land \\
PROTAX(I) & Producer tax \\
SALTAX & Sales tax \\
TM(I) & Tariff rate \\
TE(I) & Export tax \\
HTAX & Direct income tax \\
PYRLTAX & Payroll tax paid by employers \\
SSTAX & Social security tax (paid by formal labor) \\
CORPTAX & Corporate tax \\
TAXWSUAG & Fee on water use in irrigation tax \\
\hline
\end{tabular}

\subsection{Dynamics}

"Dynamics" into the model is integrated via sequentially updating of the annual "solutions" of the model up to 2030. Economic growth is the end result of (i) exogenous growth of labor supplies; (ii) investments on physical capital stocks net of depreciation allowances; and (iii) total factor productivity (TFP) growth. TFP growth is regarded exogenous, and yet, under policy scenarios we specify an endogenous feedback from the taxation funds earmarked to generate productivity gains. In-between periods, first we update the capital stocks with new investment expenditures net of depreciation. Labor supplies are increased by the respective population growth rates. Similarly, technical factor productivity rates are specified in a Hicks-neutral manner, and are introduced exogenously. Urban real wage rate is updated by the cost of living level index (endogenously solved). We further account for the evolution of debt stocks through a two step formulation: First, public foreign borrowing is taken as a ratio to public sector borrowing requirement (PSBR),

eForBor $^{G}=($ gfborrat $)$ PSBR

so that domestic borrowing becomes:

DomBor $=(1-$ gfborrat $)$ PSBR

Then, we follow the domestic and foreign debt stock accumulation of the public sector by a simple accounting rule:

DomDebt $_{t+1}=$ DomDebt $_{t}+$ DomBor $_{t}$

ForDebt $_{t+1}^{G}=$ ForDebt $_{t}^{G}+$ ForBor $_{t}^{E}$

Private foreign debt stock accumulates in the same manner:

ForDebt $_{t+1}^{P}=$ ForDebt $_{t}^{P}+$ ForBor $_{t}^{E}$

Finally, capital and labor growth follow standard specifications:

$\bar{K}_{t+1}^{S}=(1-d p r t) K_{t}^{S}+\sum_{i}\left(I D P_{i}+I D G_{i}\right)$

$\bar{L}_{t+1}^{S}=\left(1+\operatorname{popgr}_{t}\right) \bar{L}_{t}^{S}$

with dprt denoting the depreciation rate, and popgr giving the rate of population growth.

\subsection{Data}

The model is built-around a multi-sectoral social accounting matrix (SAM) of the Turkish economy based on the Turkish Statistical Institute (TurkStat) 2002 Input Output Data [33]. The 2002 I-O data had been updated to 2010 using the national income statistics. The SAM data is further tabulated from various other sources as narrated below.

Sectoral employment is taken from TurkStat. Household Labor Force Surveys (HLFS) give employment levels in detailed sectoral aggregation. This data is complemented by wage share data of the ILO (2014) and was corrected for using the self-reported household incomes as reported in the HLFS [34]. Data on domestic and foreign debt and foreign trade data are calculated from the balance of payments statistics of the TR Central Bank. All exogenous flows of foreign capital and remittances are lumped under one item as net transfers to the private household. (6.5\% of the 2010 GDP).

The I/O table already conveys information on the source and directions of flow of the energy and $\mathrm{CO}_{2}$ and PM10 emissions across the production sectors of the Turkish economy. The electricity production sector creates the highest demand for coal and petroleum and gas as the primary energy inputs. (The next two "individual" sectors are cement production (CE) and the iron and steel industries (IS)). As one of the main sources of $\mathrm{CO}_{2}$ emissions and PM10 discharges, the model identifies energy use (fuel combustion) as a key activity. TurkStat data indicate that total gaseous emissions reach 439.7 million tons of $\mathrm{CO}_{2}$ equivalent as of 2012. This sum is reported to be generated from four sources: energy, agricultural processes, industrial processes, and household waste.

\section{Results}

\subsection{The business-as-usual path}

We now turn to the analysis of alternative policy characterizations with the aid of our analytical model. It has to be noted at the outset that the purpose of the exercise is not that of projecting into the future; but rather to make comparative assessments of alternative policy environments within the discipline of general equilibrium. To this end, we will need a "benchmark" growth path to contrast and compare our alternative policy scenarios. This "business-as-usual" (BAU) path follows the observed historical patterns of technological change both in the production of sectoral output and emissions of pollutants under the exogenous flows foreign capital, fiscal accounts and other policy variables, and behavioral parameters.

The BAU path needs further assumptions to characterizes its long run dynamic equilibrium. We invoke the following:

- Rural labor supply is assumed to expand by 1\% over 2011-2020; with a gradual reduction to $0.7 \%$ by 2030 . Urban labor supply is projected to expand by $0.5 \%$ over the entire horizon. These rates are based on projections of the Ministry of Labor and Social Security;

- A major source of growth is gains in total factor productivity (TFP). Following World Bank (2014) [48], we set the average TFP growth of the urban economy at $0.8 \%$ over the whole dynamic path. Kolsuz and Yeldan [35] estimate that the average rate of TFP growth over the 2000-2010 period had been on the order of $1.1 \%$ per annum Given lack of detailed estimates, we set the average TFP growth $(0.8 \%)$ to all urban sectors equally. For agriculture, TFP is set at $0.5 \%$. Under the policy scenarios below, an endogenous specification of TFP growth will further be accommodated.

- The final source of growth for the model economy is accummulation of physical capital. This is endogenously achieved by investments (by sector of destination). Aggregate investment fund is generated through domestic and foreign savings. Domestic savings is driven by given saving rates out of private disposable income (the neoclassical closure), while foreign savings is the resolution of exogenously given net foreign inflows.

- Finally, upon this dynamic path we maintain all the existing policy rate and ratios at their given levels -hence the idea of "business-asusual”. 
Simulation of the 2015-2030 period under these specifications yields the "business-as-usual" trajectory. Relevant aspects of this trajectory is summarized in the first three columns of Table 4 below. We find that aggregate real GDP grows at an annual rate of $4.8 \%$ over this period to reach TL3,012 billion by 2030 (in fixed 2010 prices). Rate of growth of consumption and investment expenditures follow roughly the same trend with the ratio of consumption to GDP maintained at $63-65 \%$, and that of investment at $24 \%$. Public sector runs a surplus in its borrowing requirement (PSBR) at about $0.5 \%$ to the GDP. Foreign deficit (current account deficit) gradually declines from $5 \%$ to the GDP in 2015 to $2.3 \%$ in 2030 . Consequently, the gap between exports and imports are expected to narrow significantly with the deficit on merchandise trade narrowing down to less than TL12 billion by 2030. This result depends significantly on the assumption of exogenously maintaining the external terms of trade as well as the endogenous adjustments on the real exchange given the hypothesized exogenous flows of foreign capital.

We find that total $\mathrm{CO}_{2}(e q)$ emissions rise secularly to reach 983 million tonnes in $2030.685 \mathrm{~m}$ tons of this aggregate is calculated to be the end of result of combustion of fuels for energy generation; while $126.4 \mathrm{~m}$ tonnes occur due to industrial processes. Emissions from agricultural processes and households' consumption activities are at $64 \mathrm{~m}$ tonnes, and $108.2 \mathrm{~m}$ tonnes, respectively. The carbon efficiency (emissions of $\mathrm{kg} /$ \$GDP) is observed to improve as revealed with the decline from $0.71 \mathrm{~kg} / \$$ GDP to 0.59 . Overall, carbonization of the Turkish economy is observed to follow closely the projected path of the real GDP. In this sense, we tend to assert that the warranted decoupling of carbonization from the GDP activity is realized at only a modest scale over the 2011-2030 BAU path. When contrasted against the historical path over the 2000s, the joint co-movement of $\mathrm{CO}_{2}(e q)$ emissions and real GDP growth is observed to diverge to some extent (see Fig. 4 for a contrast).

\subsection{In search for alternative policy environments of abatement and greening}

In contrast to the BAU path narrated in the previous subsection, we now turn to the investigation of alternative policy environment of greening. Our main policy instrument here will be taxation of carbon emissions to be imposed at source. To make the issue explicit, we will utilize the OECD definition which states that "carbon taxes is a form of explicit carbon pricing; referring to a tax directly linked to the level of carbon emissions, often expressed as a value per tonne $\mathrm{CO}_{2}$ equivalent" [47] (emphases ours). Carbon taxes have the advantage of being explicit and certain on the extent of coverage. Yet, it has the known disadvantage where the expected level of abatement (expected rate of reductions in emissions) is not known beforehand. Nevertheless, carbon taxation is observed to be a significant part of the arsenal of environmental policy instruments across a wide spectrum of countries. Countries such as Denmark and Finland, for instance, had adopted a form of a carbon tax as early as 1990. The Danish carbon tax encompasses combustion of fossil fuels with a partial exemption of sectors that participate to the EU Emission Trading System (ETS); whereas the Finnish tax system mostly operates along a mixture of a carbon and energy tax. As of 2014 the Danish tax rate is $\$ 31$ per tonne of $\mathrm{CO}_{2}(e q)$ and the Finnish case is at Eur35 per tonne of $\mathrm{CO}(e q)$ [48]. Similar policies are seen across a variety of countries with a tax rate (per tonne of $C O 2(e q)$ ): France, \$10; Ireland, Eur20; Mexico, Mex\$1050; Norway, \$4-69; Sweeden, \$168; and Switzerland, \$68 (all 2014 levels, respectively).

Given these historical experiences, we propose to introduce a tax on emissions, across the board, for all polluters (enterprises, as well as households). We further extend our tax base on urban waste (both solid and water) by imposing proper fees of waste treatment. We summarize our menu of tax/fee interventions in Table 2.

As can be expected, our intervention is quite sizable; according to our policy simulations, environmental taxes reach to $1.9 \%$ in 2015 and to $2.6 \%$ in 2030 . We utilize these tax monies to earmark a wage fund for creating "green" jobs by the public sector. To do so we design a new set of abatement activities through the adoption of a new (public) sector. This new "abatement sector" is thought to employ urban formal labor at the ongoing wage rate $\bar{W}$. Thus, given the wage fund generated by the environmental tax revenues, "green" employment at the abatement sector, $L^{G R N}$, can be found simply as:

$\bar{W} \cdot \sum L_{k}^{G R N}=\sum\left(\right.$ taxrev $\left._{k}\right)$

Above, $L_{k}^{G R N}$ stands for employment at the $k$-th category of environmental abatement activities. As $\bar{W}$ is given in real terms, the urban formal labor market is closed through quantity adjustments on employment. With the extra demand coming from $L_{k}^{G R N}$, level of unemployment is effectively reduced, leading to a win-win outcome.

$U N E M P=L_{\text {formal }}^{\text {SUP }}-\sum_{i} L D_{i}-\sum_{k} L_{k}^{G R N}$

"Green jobs" is a burgeoning literature with accumulated evidence that the renewable energy sectors yield more jobs in comparison to sectors that operate mostly through fossil fuel combustion (see, e.g. Engel and Kammen and Kammen et al. [36,37]) Pollin and his associates further argue that a "green" recovery program may serve as a viable strategy in combatting the current recessionary environment (Pollin et al., [38]). In the Turkish context we are aware of only ArliYilmaz's [39] work in documenting the size and characteristics of green

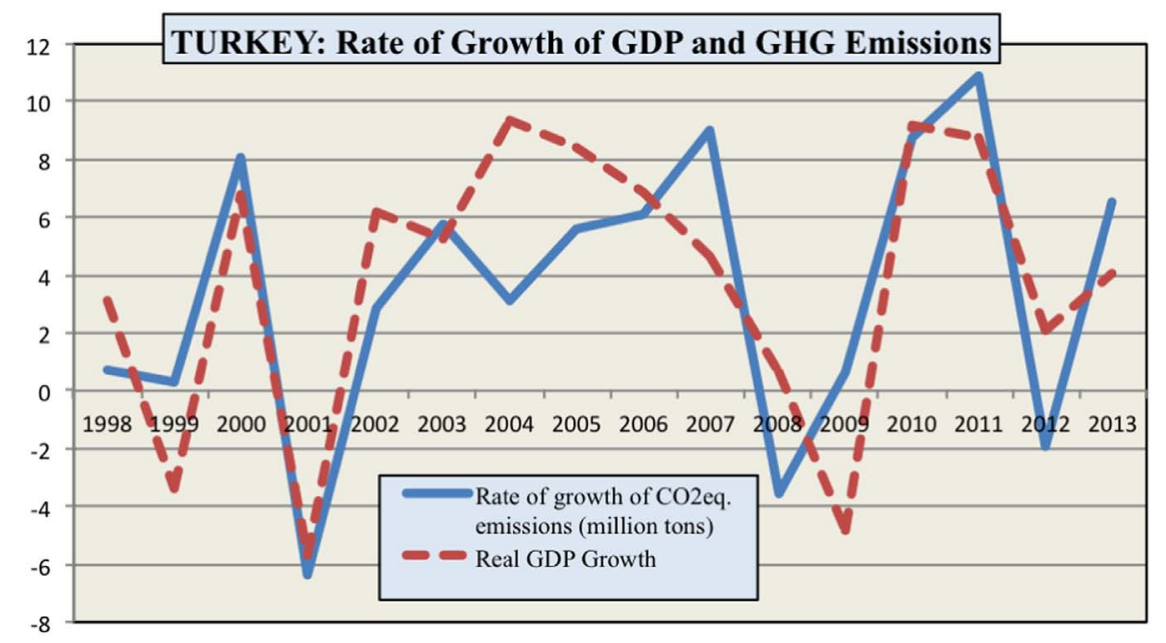

Fig. 4. Turkey: Rate of Growth of GDP and GHG Emissions. 
employment opportunities, albeit at a very narrow scale.

The understanding from this structure is that the green employees will be charged with the task of reducing $\mathrm{CO}_{2}(e q)$ and PM10 emissions, as well as urban waste. Given the size of the "green" employees, $L_{k}^{G R N}$, abatement activities lead to reductions in emission/waste coefficients, $\zeta_{k}$, via

$\Delta \zeta_{k}=e^{-\alpha_{k} L_{k}^{G R N}}$

where $\Delta$ is the change (reduction) operator on the k-th type of pollutant (with $\zeta_{k}$ denoting the pollution intensity), and $\alpha_{k}$ is a calibration parameter. $^{4}$

Fruits of abatement are not limited to reduction in pollutant intensities. We suggest further that reductions in pollution from PM10 emissions and waste will likely promote positive health spillovers on the productivity of the labor force. Given the rate of reductions in pollution over that of the base run trajectory $\left(\begin{array}{c}P_{0 l_{t}-P o l_{t}^{B A S E}} \\ P o l_{t}^{B A S E}\end{array}\right)$, we hypothesize efficiency gains that reflect such spillovers via a simple form:

$\Delta A X_{k}=e^{-\gamma_{k} \frac{\left(\text { Pol }_{t}-\text { Pol }_{B A S E}\right)}{\text { Pol }_{B A S E}}}$

The specification of the efficiency gains is adopted from de Melo and Robinson (1992) for the case of generating productivity gains from trade externalities [40] Our numerical specification is based on the estimates provided in World Bank (2013) [41] where it is argued that in the absence of policy correction, current trends in PM10 pollution will likely cost around $0.8-2.9 \%$ of the Turkish GDP over 2010-2030. WHO and US EPA, on the other hand, report even higher estimates for loss of efficiency reaching to as much as $4.5 \%$ to the GDP [41]. In our analyses we calibrate the efficiency gains at the lower estimate of $0.8 \%$ of the GDP; by way pf setting $\gamma_{k}$ at 2.000 .

\section{Policy discussion}

Now we turn to our simulation results. Utilizing the tax structure identified in Table 2 above, the model solves endogenously for the extend of environmental taxes/fees. According to model's suggestions, total environmental taxes range from $1.87 \%$ (2015) to $3.58 \%$ (2030) as a ratio to the GDP. The CO2 tax by itself accounts for $0.18-0.69 \%$, respectively.

The carbon tax re-directs incentives to utilize less of fossil fuels and coal in energy generation, leading to lower emissions. We find that by 2030 total $\mathrm{CO} 2$ emissions are reduced by $17 \%$ to $722.6 \mathrm{~m}$ tonnes. $\mathrm{CO}_{2}$ emissions due to energy operations are reduced at a more significant rate, by $33 \%$ from $685 \mathrm{~m}$ tonnes to $456.8 \mathrm{~m}$ tonnes; while emissions from industrial processes are cut by $13 \%$. Yet, abatement of CO2 come at the expense of output production. In comparison to the base trajectory, the imposition of the carbon tax leads to a fall in aggregate GDP by $7.3 \%$. Thus, the main mechanism for the fall in aggregate $\mathrm{CO}_{2}$ emissions operate through the scale effect in adjusting production activities downwards. Weighed against the gains in abatement against the loss of GDP, we find an elasticity figure of 3.7 (rate of change in total emissions, contrasted against the rate of change in GDP).

At the background of these numbers various general equilibrium dynamics are at work. Green jobs are created through the mechanics of Eq. (21) above, bringing green employment to 804 thousands in 2030. This factor leads to an additional $1.1 \%$ gain in private disposable income. Both private consumption and investment expenditures are invigorated, and compensates for the otherwise bigger loss in the GDP.

At the final score, carbon efficiency is enhanced as total $\mathrm{CO} 2$ emissions per $\$$ GDP is reduced to $0.47 \mathrm{~kg}$ in 2030 , in contrast to the base trajectory figure of $0.59 \mathrm{~kg} / \$ \mathrm{GDP}$.

The next question is: can we improve upon this macroeconomic

\footnotetext{
${ }^{4}$ In the numerical simulations $\alpha_{k}$ is set arbitrarily to 1000 for all $k$.
}

environment? Under the current scenario we have witnessed that despite gains in abatement (at the rate of $17 \%$ of total $\mathrm{CO}_{2} e q$, a loss of real GDP was realized amounting to $7.3 \%$; both are against the base path 2030 observations). Now we proceed with an investigation of a possible viable alternative macroeconomic environment to achieve a superior outcome over the EXP-1 scenario studied above. Given that the mechanism of adjustment rests ultimately with the re-allocation of labor across sectors in response to the cost signals, we focus directly on the structure of the labor markets.

It is a well-known fact of the Turkish fiscal structure that the main revenue source of fiscal income rests on the taxation of labor incomes, levided on source. On average the tax burden on labor employment is reported to reach $23 \%$ of aggregate wage and salary income (Yeldan [42]); and with employers' share of the social security premium reaching to 30\% of the total labor costs over 2008-2012 (Duman [43]). Ercan and Tansel (2006) argue that due to the bureaucratic obstacles and the high tax burden on labor employment, Turkey suffers from having one of the most rigid labor market structures among the OECD economies [44].

Rigidity emanating from the bureaucratic institutional impasse and high tax burden had also been discussed within a CGE modeling framework in Telli et al. [21] and Bekmez et al. [45], and their role was further highlighted in the environmental policy agenda by Kumbaroglu [31] and Telli et al. [29]. Similar observations were also resonated in Hassan and Nhemachena [28] and Devarajan et al. [46] who argued in their study of the climate change policies for South Africa, that adjustment costs within a rigid labor market structure can be substantial.

Based on these observations, we study a second policy environment, EXP-2, that combines the instruments of taxation of the previous EXP1 policy experiment within a macroeconomic environment where the (formal) labor market is characterized by full flexibility and the fiscal tax burden on labor employment is effectively reduced. More formally, the EXP-2 policy environment simulates the general equilibrium dynamics where (i) formal labor market wage rate is now regarded as fully flexible to clear the formal labor market; and (ii) the existing labor taxes are cut by half. We report the results of this scenario under the last three columns of Table 3.

Technically, reduction of the tax revenues leads the government to resort to re-adjustments in public expenditures to maintain fiscal balances. In comparison to the base-path (2030 values) public revenues fall by $31 \%$ as a share of GDP. Public investment and consumption expenditures both fall by $0.8 \%$ and $1.7 \%$, respectively. These Keynesian contractions are compensated, however, by the supply-side gains originating from the cost reductions achieved in the formal labor market. Consequently, labor employment expands by $9.2 \%$ over the business-as-usual (base path) trajectory; and by 25\% over the EXP-1. About a third of this added employment ( 957 thousand workers) is due to the emergence of "green employment". Green wages carry about $1.1 \%$ additional disposable income to the private sector. As a result of these favorable outcomes, the GDP expands, and, in comparison to the base path, reaches to a $1.6 \%$ higher value as of 2030 .

The expansion of the GDP is clearly due to the result of a more rational tax structure where the distortionary labor taxes are effectively reduced and compensated in part by the environmental taxes. Thus, we effectively achieve higher employment together with gains in pollution abatement. Total $\mathrm{CO}_{2}$ (eq) emissions are reduced by $5.6 \%$ in 2020 , and by $19.7 \%$ in 2030 . It has to be noted that the aggregate level of $\mathrm{CO}_{2}(\mathrm{eq})$ emissions reach to a higher level in comparison to the EXP-1 scenario (exceeding the 2030 level by $9.2 \%$ ). This is due to the invigorated production activity and the expansion of the GDP over the EXP-1 scenario. Higher economic activity, both from the production and private expenditure side, leads to increased emissions of pollutants (due to the rebound effect). However, given the expansion of GDP, the scenario achieves significant gains in carbon efficiency; aggregate $\mathrm{CO}_{2}$ emissions per \$GDP fall to $0.46 \mathrm{~kg}$ in 2030, and bring Turkey closer to 
Table 3

Summary Results: Base Path versus Urban Greening Policy Scenarios.

\begin{tabular}{|c|c|c|c|c|c|c|c|c|c|}
\hline & \multicolumn{3}{|c|}{ Base Path } & \multicolumn{3}{|c|}{ EXP1: Greening Urban Economy via "Green" Jobs } & \multicolumn{3}{|c|}{ EXP2: EXP1+Labor Market Reform } \\
\hline & 2015 & 2020 & 2030 & 2015 & 2020 & 2030 & 2015 & 2020 & 2030 \\
\hline \multicolumn{10}{|l|}{ Results (Billion $T L, 2010$ fixed prices) } \\
\hline Real GDP & 1443.8 & 1863.5 & 3012.7 & 1418.5 & 1796.9 & 2795.9 & 1487.5 & 1906.2 & 3060.9 \\
\hline Aggregate Investment & 290.6 & 361.5 & 554.1 & 285.7 & 349.0 & 512.5 & 286.1 & 354.2 & 538.9 \\
\hline Aggregate Private Consumption & 996.8 & 1278.0 & 2074.9 & 967.4 & 1211.0 & 1869.4 & 1072.2 & 1359.7 & 2169.9 \\
\hline Exports & 337.2 & 462.7 & 828.2 & 316.3 & 419.6 & 697.8 & 335.3 & 451.5 & 779.1 \\
\hline Imports & 384.9 & 498.6 & 840.6 & 363.9 & 455.5 & 710.2 & 382.9 & 487.4 & 791.4 \\
\hline \multicolumn{10}{|l|}{ Environmental Pollution Indicators (Million Tons) } \\
\hline Solid Waste: Total Industry & 19.3 & 28.1 & 58.4 & 7.0 & 3.3 & 1.4 & 7.1 & 3.3 & 1.4 \\
\hline Solid Waste: Household & 33.9 & 43.5 & 70.6 & 15.7 & 6.8 & 2.9 & 15.9 & 6.7 & 2.8 \\
\hline Water Pollution: Total Industry (Billion liters) & 1.6 & 2.4 & 5.1 & 1.1 & 1.5 & 2.3 & 1.2 & 1.6 & 2.6 \\
\hline Water Pollution: Household (Billion liters) & 4.9 & 6.3 & 10.3 & 4.8 & 6.0 & 9.3 & 5.3 & 6.7 & 10.8 \\
\hline PM10: Total & 2599.1 & 3038.5 & 4045.5 & 2431.9 & 2647.3 & 2759.0 & 2558.3 & 2819.1 & 3011.1 \\
\hline PM10: Energy Related & 1995.9 & 2252.4 & 2753.2 & 1851.4 & 1913.6 & 1626.2 & 1931.4 & 2015.5 & 1728.7 \\
\hline PM10: Industrial Processes & 356.7 & 473.4 & 791.3 & 343.2 & 440.3 & 688.1 & 360.0 & 468.3 & 756.3 \\
\hline PM10: Households & 246.5 & 312.7 & 501.1 & 237.3 & 293.3 & 444.7 & 267.0 & 335.2 & 526.0 \\
\hline $\mathrm{CO}_{2}$ eq: Total & 568.9 & 689.9 & 983.7 & 534.8 & 612.1 & 722.6 & 562.3 & 651.3 & 789.4 \\
\hline $\mathrm{CO}_{2}$ eq: Energy related & 421.9 & 502.5 & 685.0 & 392.3 & 435.3 & 456.8 & 409.3 & 458.9 & 490.6 \\
\hline $\mathrm{CO}_{2}$ eq: Industrial Processes & 57.0 & 75.7 & 126.4 & 54.8 & 70.4 & 110.0 & 57.5 & 74.8 & 120.9 \\
\hline $\mathrm{CO}_{2}$ eq: Agriculture & 36.7 & 44.2 & 64.0 & 36.4 & 43.1 & 59.8 & 37.9 & 45.1 & 64.2 \\
\hline $\mathrm{CO}_{2}$ eq: Households & 53.2 & 67.5 & 108.2 & 51.3 & 63.3 & 96.1 & 57.7 & 72.4 & 113.6 \\
\hline \multicolumn{10}{|l|}{ Pollutant Intensities $(\mathrm{kg} / \$ G D P)$} \\
\hline Total $\mathrm{CO}_{2} / G D P(\mathrm{~kg} / \$ G D P)$ & 0.71 & 0.67 & 0.59 & 0.68 & 0.61 & 0.47 & 0.68 & 0.61 & 0.46 \\
\hline Total $P M 10 / G D P(\mathrm{~kg} / \$ G D P)$ & 3.24 & 2.93 & 2.42 & 3.09 & 2.65 & 1.78 & 3.1 & 2.66 & 1.77 \\
\hline Total Industrial Waste/GDP $(\mathrm{kg} / \$ G D P)$ & 0.02 & 0.03 & 0.03 & 0.01 & 0.00 & 0.00 & 0.00 & 0.00 & 0.00 \\
\hline Total Household Waste/GDP $(\mathrm{kg} / \$ G D P)$ & 0.04 & 0.04 & 0.04 & 0.02 & 0.01 & 0.00 & 0.00 & & 0.00 \\
\hline \multicolumn{10}{|l|}{ Environmental Taxes (Fees) (\% Ratios to the GDP) } \\
\hline Total Waste Fees: Industry & & & & 0.52 & 0.38 & 0.21 & 0.50 & 0.35 & 0.18 \\
\hline Total Waste Fees: Households & & & & 0.55 & 0.38 & 0.21 & 0.54 & 0.35 & 0.18 \\
\hline Total Water Pollution Fees: Industry & & & & 0.16 & 0.34 & 0.69 & 0.17 & 0.35 & 0.70 \\
\hline Total Water Pollution Fees: Households & & & & 0.17 & 0.33 & 0.66 & 0.18 & 0.35 & 0.70 \\
\hline Total $P M 10$ Taxes & & & & 0.28 & 0.56 & 1.12 & 0.29 & 0.57 & 1.13 \\
\hline Total $\mathrm{CO}_{2}$ Taxes & & & & 0.18 & 0.35 & 0.69 & 0.18 & 0.36 & 0.71 \\
\hline Total Environmental Taxes (Fees) (\% of GDP) & & & & 1.87 & 2.35 & 3.58 & 1.85 & 2.33 & 3.61 \\
\hline \multicolumn{10}{|l|}{ Employment (Million workers) } \\
\hline Total Employment in Production & 24.006 & 24.451 & 25.960 & 22.957 & 22.746 & 22.680 & 26.414 & 27.166 & 28.373 \\
\hline Urban Employment & 20.232 & 21.409 & 23.566 & 19.169 & 19.682 & 20.260 & 22.307 & 23.738 & 25.589 \\
\hline Rural Employment & 3.774 & 3.042 & 2.394 & 3.788 & 3.064 & 2.421 & 4.107 & 3.428 & 2.784 \\
\hline "Green" Employment & & & & 0.609 & 0.636 & 0.804 & 0.657 & 0.706 & 0.957 \\
\hline Total Employment & 24.006 & 24.451 & 25.960 & 23.566 & 23.382 & 23.484 & 27.071 & 27.873 & 29.330 \\
\hline $\begin{array}{l}\text { Ratio of "Green" Wages to Private Disposable } \\
\text { Income }\end{array}$ & & & & 0.897 & 0.925 & 1.144 & 0.832 & 0.853 & 1.080 \\
\hline \multicolumn{10}{|l|}{ Fiscal Balances (Ratios to the $G D P$ ) } \\
\hline Government Revenues & 25.43 & 25.38 & 25.40 & 26.42 & 26.75 & 27.65 & 21.02 & 21.36 & 22.31 \\
\hline Public Investment & 4.54 & 6.53 & 6.54 & 4.80 & 6.88 & 7.12 & 3.41 & 5.50 & 5.74 \\
\hline Public Consumption & 14.10 & 14.07 & 14.08 & 14.64 & 14.83 & 15.32 & 11.65 & 11.84 & 12.37 \\
\hline Public Sector Borrowing Requirement & -1.10 & 0.46 & 0.45 & -1.05 & 0.52 & 0.54 & -1.15 & 0.42 & 0.42 \\
\hline Memo: Foreign Deficit & 5.02 & 3.88 & 2.33 & 5.20 & 4.12 & 2.62 & 4.94 & 3.85 & 2.36 \\
\hline
\end{tabular}

the OECD averages (see Table 1 above).

The resolution of the alleged trade-off between environmental protection measures and GDP growth can be expressed more technically with the documentation of the marginal abatement cost (MAC) calculations. The MAC curve portrays the path of abatement adjustments of the $\mathrm{CO}_{2}$ (eq) emissions and other pollutants in return for the imposed environmental taxes/fees on the relevant polluter. ${ }^{5}$

The model results reveal that the MAC for $\mathrm{CO} 2(e q)$ in EXP-2 reaches to $44 \$ /$ ton in $2019 / 20$, and then gradually recedes to $40 \$ /$ ton; while that for the EXP-1 maintains its upward trend to $46 \$ /$ ton. This increased efficiency of the imposed carbon tax is due to the rationalized tax structure together with a flexible institutional environment in the

\footnotetext{
${ }^{5}$ More technically: for pollutant $k ; M A C_{k}=\frac{\operatorname{Pol}_{t}^{E X P}-P_{o l}{ }_{t}^{B A S E}}{\Delta \operatorname{Tax}_{k, t}}$.
}

labor markets under EXP-2.

The MAC curves against $\mathrm{CO}_{2}$ mitigation under the alternative policy scenarios are displayed in Fig. 5.

The modeling message is clear: harmonization of instruments of mitigation against climate change with a more rational tax structure on labor markets along with macroeconomic policies to promote employment in green production activities, developing economies can achieve significant gains towards a sustainable green growth path with higher employment.

\section{Conclusion and policy implications}

In this paper we studied the arsenal of micro and macro economic policies towards sustainable and green(er) growth in an environment characterized by institutional rigidities and a high tax burden on the 


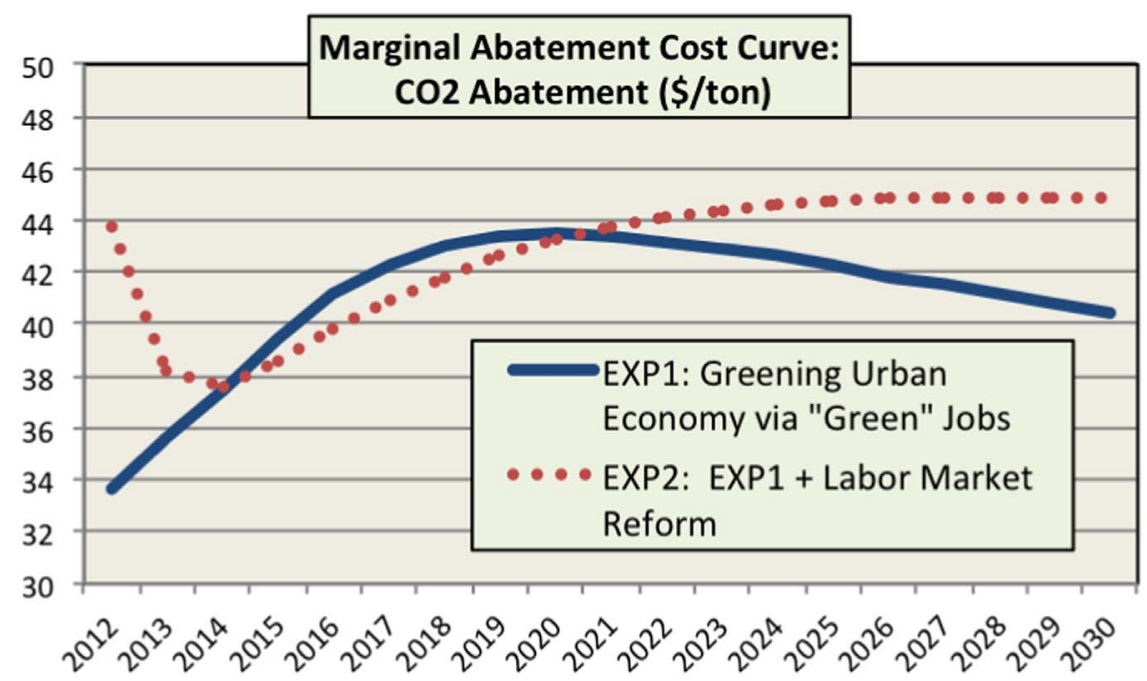

Fig. 5. Marginal Abatement Cost Curve: $\mathrm{CO}_{2}$ Abatement.

labor markets, and aspirations for rapid growth in the face of higher pressures for population growth. We note that these are among the typical realities of a developing economy; and using data from Turkey we utilized an applied general equilibrium model as a laboratory device, and sought for policies towards simultaneous achievement of sustainable patterns of growth together with environmental pollution abatement, increased employment opportunities, and a higher rate of disposable income. This triple-dividend of win-win-win strategy framework rests on rationalization of the tax funds to stimulate innovations towards greener technologies.

With the aid of our analytical model we simulated over the 20152030 trajectory of the Turkish economy under assumptions of "business-as-usual". Our modeling exercise revealed that, given real rate of GDP growth at $5 \%$ per annum, aggregate $\mathrm{CO}_{2}(\mathrm{eq})$ emissions will reach to 983.7 million tonnes. This is a cumulative increase of 2.2-folds over the 2014 estimates of Turkey's $\mathrm{CO}_{2}$ (eq) emissions. We calculate that the $\mathrm{CO}_{2}(\mathrm{eq})$ intensity with respect to $\$ \mathrm{GDP}$ is reduced to $0.59 \mathrm{~kg}$ in 2030 from its peak of $0.71 \mathrm{~kg}$ in 2015; it nevertheless falls significantly behind of the OECD averages.

To combat these realizations, we first implemented a policy intervention of introducing environmental taxes on pollutants. As a further unique step, we also introduced an institutional mechanism to earmark these tax revenues in creating a public wage fund for green employment tasks. The scenario is observed to achieve significant gains in mitigation where aggregate $\mathrm{CO}_{2}$ (eq) emissions were reduced by $17.1 \%$ in 2030 over the business-as-usual base path; and yet its effects were realized to be contractionary with a loss of GDP by $7.2 \%$. Consequently, an alternative specification was sought to achieve a more rational fiscal tax burden together with a call for more flexibility in the labor markets. Combining a fiscal tax reduction policy of cutting the existing labor taxes by half within a more flexible labor market specification, we attempted to rationalize the rigid tax structure of the Turkish economy.

Under this scenario, we found that labor employment expands by 9.2\% over the business-as-usual. Green wages carry about $1.1 \%$ additional disposable income to the private sector. As a result of these favorable outcomes, the GDP expands, and, in comparison to the base path, reaches to a $1.6 \%$ higher value as of 2030 . Total $\mathrm{CO}_{2}(\mathrm{eq})$ emissions are reduced by $5.6 \%$ in 2020 , and by $19.7 \%$ in 2030 . This brings significant gains in carbon efficiency; aggregate $\mathrm{CO}_{2}$ emissions per \$GDP fall to $0.46 \mathrm{~kg}$ in 2030, and bring Turkey closer to the OECD averages.

Based on our analytical exercises we argue that by harmonization of instruments of mitigation against climate change with a more rational tax structure on labor markets along with macroeconomic policies to promote employment in green production activities, developing economies can achieve significant gains towards a sustainable green growth path with higher employment.

\section{References}

[1] Rodrik Dani. One economics, many recipes: globalization, institutions, and economic growth. N.J.: Princeton University Press; 2007.

[2] Rodrik Dani. Second Best Institutions. NBER Working Paper No. 14050, June; 2008.

[3] Rodrik Dani. Green Industrial Policy Institute for Advanced Study. Princeton, N. J. unpublished mimeo; 2013.

[4] Aghion P, Boulanger Julian, Cohen Elie. Rethinking Industrial Policy Bruegel Policy Brief No 04, June; 2011.

[5] Romer Paul M. Endogenous Technological Change. Journal of Political Economy, University of Chicago Press, vol. 98(5): October; 1990. p. S71-102.

[6] Krugman Paul. Increasing Returns and Economic Geography. Journal of Political Economy, University of Chicago Press, vol. 99(3); June 1991, p. 483-99.

[7] Aghion P. Industrial Policy for Green Growth. Paper presented at the 17th World Congress of the International Economics Association, Jordan; 2014.

[8] Lozschel Andreas. Technological change in economic models of environmemtal policy. A Surv Ecol Econ 2002;43:105-26.

[9] Goulder LH, Mathai Koshy. Optimal $\mathrm{CO}_{2}$ abatement in the presence of induced technological change. J Environ Econ Manag 2000;39(1):1-38.

[10] Nordhaus, W, Boyer J. Roll the DICE again: The Economics of Global Warming. New Haven: Yale University Press.

[11] Buonanno P, Carraro C, Galeotti M. Endogenous Induced Technical Change and Costs of Kyoto Nota di Lavoro No 64. FEEM, Milan Italy; 2001.

[12] Griliches Z. The search for R \& D spillovers. Scand J Econ 1992;94:29-47.

[13] Goulder LH, Schneider S. Induced technological change, crowding out and the attractiveness of $\mathrm{CO}_{2}$ emissions abatement. Resour Environ Econ 1999;21(34):211-53.

[14] Porter M, van der Linde C. Toward a new conception of the environmentcompetitiveness relationship. J Econ Perspect 1995;9(4):97-118.

[15] Ambec S, Cohen MA, Elgie S, Lanoie P. The Porter Hypothesis at 20: Can Environmental Innovation Enhance Innovation and Competitiveness? Resources for the Future Discussion Paper 11-01; 2011.

[16] Braanlund R, Lundgren T. Environmental policy without costs? A review of the porter hypothesis. Int Rev Environ Resour Econ 2009;3(2):75-117.

[17] Kuralbayeva Karlygash. Effects of Carbon Taxes in an Economy with Large Informal Sector and Rural-Urban Migration Grantham Research Institute Research paper. mimeo; 2013.

[18] Bowen Alex. Green Growth, Green Jobs and Labour Markets Centre for Climate Change Economics and Policy. Working paper no 88, University of Leeds; 2012.

[19] Goulder LH. Effects of carbon taxes in an economy with prior tax distortions: an intertemporal general equilibrium analysis. J Environ Econ Manag 1995;29:271-97.

[20] Bovenberg A, de Mooij Ruud A. Environmental taxes and labor-market distortions, European Journal of Political Economy, Elsevier, vol. 10(4); December 1994, p. 655-83.

[21] Telli C, Voyvoda E, Yeldan E. Modeling General Equilibrium for Socially Responsible Macroeconomics: Seeking for the Alternatives to Fight Jobless Growth in Turkey METU Studies in Development, No. 33; August 2007.

[22] Akin Olcum, Gokce, Erinç Yeldan A. Economic impact assessment of Turkey's postKyoto vision on emission trading, Energy Policy, Elsevier, vol. 60(C); 2013. p. 76474.

[23] Adaman Fikret, Karalı Nihan, Kumbaroglu Gurkan, Or Ilhan, Ozkaynak Begum, 
Zenginobuz Unal. What determines urban households' willingness to pay for CO 2 emission reductions in Turkey: A contingent valuation survey. Energy Policy 2011;39.2:689-98.

[24] Așıcı Ahmet Atıl. On the susrainability of the economic growth path of Turkey, 1995 - 2009. Renew Sustain Energy Rev 2015;52:1731-41.

[25] Acar Sevil, Erinç Yeldan A. Environmental Impacts of Coal Subsidies In Turkey: A General Equilibrium Analysis Energy Policy, 90; March 2016, p. 1-15.

[26] Pigou AC. The economics of welfare. London: MacMillan; 1920.

[27] Fullerton D, Metcalf G. Environmental controls, scarcity rents and pre-existing distortions. J Public Econ 2001;91:571-91.

[28] Devarajan S, Go D, Robinson S, Thierfelder K. Tax policy to reduce carbon emissions in a distorted economy: illustrations from a South Africa CGE model. B E J Econ Anal Policy 2011;11(1).

[29] Telli C, Voyvoda E, Yeldan E, Economics of environmental policy in Turkey: a general equilibrium investigation of the economic evaluation of sectoral emission reduction policies for climate change. J Policy Model 2008;30(1):321-40.

[30] Sahin Sebnem. An Economic Policy Discussion of the GHG Emission Problem in Turkey from a Sustainable Development Perspective within a Regional General Equilibrium Model: TURCO, Unpublished Doctoral Dissertation submitted to the Université Paris I Panthéon - Sorbonne; February 2005.

[31] Kumbaroglu Selcuk G. Environmental taxation and economic effects: a computable general equilibrium analysis for Turkey. J Policy Model 2003;25:795-810.

[32] Bouzaher Aziz, Sebnem Sahin, Yeldan A Erinç. How to go green? A general equilibrium investigation of environmental policies for sustained growth with an application to Turkey. Lett Spat Resour Sci 2015;8(1):49-76.

[33] ]Turkish Statistical Institute. Input-Output Tables for Turkish Economy. 〈http:// www.turkstat.gov.tr/PreTablo.do?Alt_id=1021).

[34] International Labor Organization. Global Wage Report. 〈http://www.ilo.org/ ilostat/GWR?_afrLoop=948294003015057\#!\%40\%40\%3F_afrLoop \%3D948294003015057\%26_adf.ctrl-stat\%3Dhbuaq3188_4〉.

[35] Kolsuz Gunes, Erinc Yeldan A. 1980-Sonrası Türkiye Ekonomisinde Büyümenin Kaynaklarının Ayrıștırılması Çalisma ve Toplum, 40, 1; 2013, p. 49-66.

[36] Engel Ditlev, Kammen Daniel. Green Jobs and The Clean Energy Economy
Copenhagen Climate Council Thought Leadership Series No 04; 2009.

[37] Kammen Daniel, Kapadia Kamal, Fripp Matthias. Putting Renewables to Work: How Many Jobs Can the Clean Energy Industry Generate? University of California Berkeley, mimeo; 2004.

[38] Pollin Robert, Garrett-Peltier Heidi. Heintz James, Scharber Helen. Green Recovery, A Program to Create Good Jobs and Start Building a Low-Carbon Economy Center for American Progress, mimeo; 2008.

[39] Arli-Yilmaz Selen. Green Jobs and their potential in renewable energy in Turkey (in Turkish) Expert Thesis, TR Ministry of Development; May 2014.

[40] De Melo J, Robinson S. Productivity and externalities: models of export-led growth. J Int Trade Econ Dev 1992;1(1):41-58.

[41] World Bank. Turkey Green Growth Policy Paper: Towards a Greener Economy, April. Washington, DC, USA; 2013.

[42] Yeldan A. Erinç. Turkey's Employment Subsidy Programme Under Great Recession: A General Equilibrium Assessment International Review of Applied Economics, forthcoming; 2017.

[43] Duman Anil. Flexicurity in Turkish Labour Markets TUSIAD and Koc University -ERF Joint paper. Istanbul; 2014.

[44] Ercan H, Tansel A. How to approach the Challenge of Reconciling Labor Flexibility with Job Security and Social Cohesion in Turkey. Research paper of the Turkish expert group preparation for European Council FORUM 2005 (Strasbourg); 2006.

[45] Bekmez S, Genc I, Kennedy L. A Computable general equilibrium model for the organized and marginal labor markets in Turkey. Southwest Econ Rev 2002:97-114.

[46] Hassan Rashid, Nhemachena Charles. Determinants of African farmers' strategies for adapting to climate change: multinomial choice analysis. Afr J Agric Resour Econ 2008;22(1):1-28.

[47] OECD (2013), Climate and carbon: aligning prices and policies, OECD Environment Policy Paper, October, No 1.

[48] World Bank 2014, Background Note: Putting a Price on Carbon with a Tax, p. 3, accessed from http://www.worldbank.org/content/dam/Worldbank/ document/ Climate/background-note_carbon-tax.pdf on January 15, 2015. 